\title{
Water Availability in Southwest Georgia and Northeast Florida'
}

\author{
Sadie Hundemer and Martha C. Monroe²
}

Stretching from Mississippi to South Carolina, the Floridan Aquifer is the primary source of fresh water for southwest Georgia and northeast Florida. Requiring minimal treatment, water from the aquifer system is inexpensive, provides drinking water for approximately 10 million people (Marella and Berndt 2005), supports major agricultural and tourism industries, and sustains unique ecosystems. As the population and economy of the region expands, demand for water from the aquifer system will continue to increase. Yet, the aquifer system's capacity is limited, and fulfilling the needs of residents, agriculture, industry, and ecosystems will require balancing water withdrawals with aquifer replenishment from rainfall, particularly in drier times.

\section{How much water is available to}

\section{use?}

The vastness of the Floridan Aquifer suggests that the region it supplies should have few water concerns. With such a vast supply, why not pump enough water to meet regional water demand? Though the aquifer system contains an immense amount of water, it is important that the aquifer system's uppermost water levels are maintained. This is because the water in the upper portion of the aquifer system (along with rainfall) feeds many of the region's lakes, rivers, streams, and springs. If excessive water is pumped from the aquifer, the effects can be seen above ground with decreasing streamflow and surface water levels, particularly at times when rainfall is low. These visible changes affect the availability of water for residential, agricultural, and industrial use as well as property values, recreation, and tourism. Lower water levels can also have long-term consequences for the region's unique ecosystems. Therefore, maintaining the water that can be seen requires maintaining the level of water that cannot be seen.

Maintaining sustainable aquifer water levels requires balancing the amount withdrawn with the amount that is added through natural processes. During rainy periods, the Floridan aquifer system recharges - it replenishes as rainwater slowly seeps downward through the soil. Significant portions of southwest Georgia and northeast Florida have the right conditions for this to happen. In these parts of the states, the soil and underlying rock allow rainwater to make this downward journey. But even in these regions, not all rainwater reaches the aquifer system. High temperatures create high rates of evaporation with much rainwater returned to the atmosphere. In forests, farms, fields, and landscaped areas, a portion of the rainwater is taken up by plants. When rain falls on soil that is saturated or on land surfaces (such as pavement) that prevent water from soaking in, rainwater flows across the land or through stormwater systems to lakes, rivers, streams, and oceans.

Florida and Georgia are fortunate to receive abundant rain to recharge the aquifer system most months of most years, but the states are also subject to dry periods and frequent prolonged droughts. In dry years, communities

1. This document is FR438, one of a series of the School of Forest, Fisheries, and Geomatics Sciences, UF/IFAS Extension. Original publication date June 2021. Visit the EDIS website at https://edis.ifas.ufl.edu for the currently supported version of this publication.

2. Martha C. Monroe, professor; and Sadie Hundemer, postdoctoral researcher; School of Forest, Fisheries, and Geomatics Sciences, UF/IFAS Extension, Gainesville, FL 32611

The Institute of Food and Agricultural Sciences (IFAS) is an Equal Opportunity Institution authorized to provide research, educational information and other services

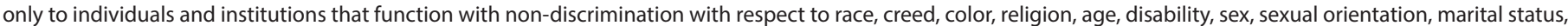

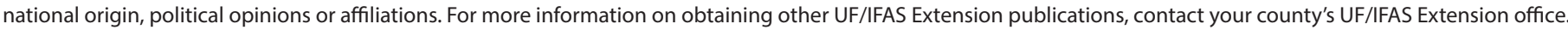
U.S. Department of Agriculture, UF/IFAS Extension Service, University of Florida, IFAS, Florida A \& M University Cooperative Extension Program, and Boards of County Commissioners Cooperating. Nick T. Place, dean for UF/IFAS Extension. 
and water users can face difficult decisions (some directed by law) about how to use a limited water supply. Therefore, continued ability to meet water needs requires planning for dry times.

\section{Withdrawals from the Floridan Aquifer System}

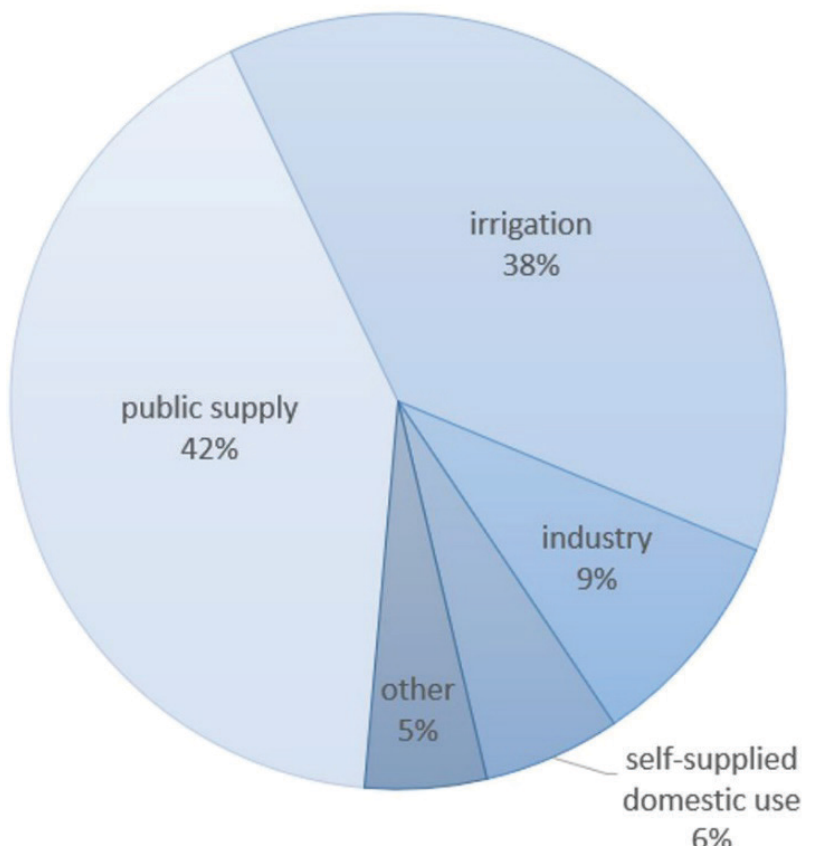

Figure 1. Data from the US Geological Society.

Credits: Lovelace et al. 2020

\section{CATEGORY DEFINITIONS}

Public supply: "water that is delivered by public or private water systems to residential and commercial customers."

Irrigation: "self-supplied water applied by an irrigation system on farms, at horticultural facilities, in recreational areas such as parks and golf courses, and in other places where water is needed to sustain plant growth."

Self-supplied domestic use: "water from private sources, such as wells, that are used for various needs at individual residences."

Industry: "groundwater and surface water associated with fabricating, processing, washing, diluting, cooling, and other processes used in the development of products, as well as water used for consumption, maintenance, and other needs at manufacturing facilities."

\section{How much water is being used?}

Over the past fifty years, withdrawals from the Floridan Aquifer increased substantially due to regional population growth, tourism, and agricultural production (Marella \& Berndt 2005). However, more recent data show declining trends. From 2000 to 2015, withdrawals of fresh water from the aquifer system for public supply, irrigation, and industry declined by approximately 27 percent (Lovelace et al. 2020). Withdrawn water is also being used more efficiently. For example, precision irrigation has enabled a gallon of aquifer water to produce more food and fiber than it did previously. Continued improvements to water-use efficiency should help ensure continued availability of ample fresh water.

\section{Planning for Balance}

When more water is withdrawn for human use than is replenished by rain, our aquifer reserves decline. If we do not protect this high quality, inexpensive, and ecologically important water supply and take care not to overuse it, residents will see higher water costs and increased wateruse restrictions. Water could become less available to agriculture and industry, decreasing the economic viability of the region. Further, the water levels in aquifer-fed surface water systems will decline, affecting wildlife habitat, recreation, tourism, and property values. Each of the strategies below can help maximize the water supply, but they vary in effectiveness and cost.

\section{Water Supply Strategies}

Increased water-use efficiency. The most effective and cost-efficient strategy for maximizing water supply is to use less water. Agricultural water-use efficiency is being increased through the installation of soil moisture sensors and irrigation technologies that allow farmers to apply water more precisely to crops. Similarly, water can be efficiently applied to lawns and landscapes though the use of soil moisture and rainfall cutoff sensors. Municipalities can decrease water loss by locating and repairing leaks in water infrastructure. Residents can also increase conservation through the installation of water-efficient fixtures and appliances, as well as mindful use of water.

Reclaimed (or recycled) water. With advanced treatment, water can be used multiple times, reducing the amount of water pumped from the aquifer system. Reclaimed water is often used for lawn irrigation, agriculture, industrial processes, and groundwater recharge (see below). Using reclaimed water for non-potable uses reserves more highquality groundwater for potable uses; however, the use of reclaimed water for irrigation without consideration of the water's nutrient content can contribute to water quality issues.

Groundwater recharge using natural processes. Instead of passively depending on rain to recharge the aquifer system, there are methods to actively increase aquifer water levels. Rapid infiltration can be achieved by ponding or spraying stormwater or wastewater in areas that have the right soil composition to treat water as it percolates downward to the aquifer system. 
Groundwater recharge using aquifer storage and recov-

ery (ASR). ASR entails the direct injection of water from excess rainfall, surface water, water from another aquifer, or treated wastewater into the aquifer for temporary storage and later withdrawal during drier times; however, there are concerns that ASR processes may decrease the quality of the aquifer water supply.

Stormwater management. Rainwater that falls on impermeable surfaces can be directed to areas that remove pollutants and replenish groundwater. Swales, for example, are shallow ditches with grassy slopes that filter the water as it enters the ground.

Reservoirs. Human-made above-ground storage facilities, such as artificial lakes, can help ensure water availability during dry periods when aquifer and surface water levels are low. Although reservoirs can provide an important buffer, they are often very costly to build and require a natural water supply to fill, which may not be reliable in dry periods. In-stream reservoirs can also disrupt ecology, such as the movement of fish.

Desalinization. Converting salt or brackish water to fresh water is an option. It is the most expensive strategy, however, requiring large amounts of energy.

\section{Summary}

If water levels decline in aquifer-fed surface water systems, there may also be a decline in wildlife habitat, recreation, tourism, property values, and the economy. However, through long-term strategic planning we can protect the region's water future.

\section{References}

Lovelace, J. K., M. G. Nielsen, A. L. Read, C. J. Murphy, and M. A. Maupin. 2020. "Estimated Groundwater Withdrawals from Principal Aquifers in the United States, 2015.” US Geological Survey 1464, p. 82. USGS, Reston, VA. https:// doi.org/10.3133/cir1464

Marella, R. L., and M. P. Berndt. 2005. "Water Withdrawals and Trends from the Floridan Aquifer System in the Southeastern United States, 1950-2000" US Geological Survey 1278. USGS, Reston, VA. http://pubs.er.usgs.gov/ publication/cir1278 